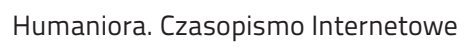

\author{
JOANNA USAKIEWICZ \\ Uniwersytet w Białymstoku \\ Instytut Filozofii \\ e-mail: j.usakiewicz@uwb.edu.pl \\ ORCID: 0000-0003-2767-4024
}

\title{
Filozoficzne i teologiczne podstawy argumentacji na rzecz edukacji kobiet w Occasional Thoughts Damaris Masham
}

\begin{abstract}
In 1705, the book titled Occasional Thoughts in Reference to a Vertuous or Christian Life was edited. Damaris Masham (1659-1708), the author of this writing, the daughter of Ralph Cudworth and the friend of John Locke presents in the work her view on women's education. This article examines the elements of rational reflection upon the world and the concept of a human being, which has led Masham to a radical for her contemporaries conclusion that the proper women's education should be necessary. Masham's arguments refer to the equality of people as rational creatures of God, their desire for salvation, defence of faith, and conveying religious teachings, but also they appeal to the significance of women's social roles as a wife and a mother.
\end{abstract}

Keywords: Damaris Masham, philosophy of the seventeenth century, women's education

W 1705 r. została wydana anonimowo książka zatytułowana: Occasional Thoughts itn Reference to a Vertuous or Christian Life (Myśli okazjonalne w zwiqzzu z cnotliwym lub chrześcijańskim życiem) ${ }^{1}$. We Wstępnie do książki zaznaczono, iż sam tekst powstał około dwóch lat wcześniej i leżał prawie zapomniany².

${ }^{1}$ [D. Masham], Occasional Thoughts in Reference to a Vertuous or Christian Life, printed for A. and J. Churchil at the Black Swan in Pater-noster Row, London 1705 (dalej: OT).

2 ,[...] these Papers lay by for above two Years unread, and almost forgotten”. OT, The Preface, brak numeracji stron. 
W Occasional Thoughts odnajdziemy więc myśli dotyczące: człowieka jako rozumnego stworzenia, jego działań, religii naturalnej i religii objawionej, związku religii z moralnością, edukacji jako środka do uczynienia ludzi cnotliwymi, czyli żyjącymi zgodnie z rozumem, a w szczególności argumentacji na rzecz kształcenia kobiet.

Początkowo istniały pewne rozbieżności co do autorstwa tego tekstu, niektórzy bowiem przypisywali go Johnowi Locke’owi ze względu na przedstawione poglądy i przywołanie traktatów Mr. L...'s: The Reasonableness of Christianity as Delivered in the Scriptura (Racjonalność chrześcijaństwa...; 1695) oraz Some Thoughts Concerning Education (Myśli o wychowaniu; 1693). W 1747 r. tekst został nawet opublikowany jako Thoughts of Christian Life by John Locke ${ }^{3}$. Jako wydane pośmiertnie dzieło Locke’a wymienia go także Abel Boyer w swojej The History of the Reign of Queen Anne. Digested into Annals. Year the Third wydanej w 1705 r. ${ }^{4}$ Podobną sugestię odnajdziemy również w liście Richarda Gwinnetta do Elizabeth Thomas z czerwca 1705 r., gdzie pisze o nim jako o the little posthumous treatise of Mr Locke ${ }^{5}$ W tym samym okresie inni jednak słusznie widzieli jako autorkę traktatu Damaris Masham (1659-1708) - córkę filozofa Ralpha Cudwortha (1617-1688) i przyjaciółkę Johna Locke’a, w której domu spędził on ostatnie lata życia ${ }^{6}$. O książce Masham wspomina, na przykład, inna myślicielka tego okresu - Catharine Cockburn (1679-1749) w liście z 12 listopada 1705 r. do biskupa Salisbury, Gisberta Burneta ${ }^{7}$. W drugiej połowie XVIII wieku atrybucja Occasional Thoughts nie budzi już wątpliwości, czego najlepszym dowodem jest umieszczenie tego pisma w dorobku Damaris Masham w pracy George’a Ballarda z 1752 r.: Memoirs of Several Ladies of Great Britain, Who Have Been Celebrated

${ }^{3}$ Thoughts on Christian Life by John Locke, T. Waller, London 1747.

${ }^{4}$ Zob. A. Boyer, The History of the Reign of Queen Anne. Digested into Annals. Year the Third, A. Roper, London 1705, s. 262.

${ }^{5}$ Pylades and Corinna: or; Memoirs of the Lives, Amours, and Writings of Richard Gwinnett and Mrs. Elizabeth Thomas, Edmund Curll, London 1731, s. 90.

${ }^{6}$ Na temat życia i dzieła Damaris Cudworth Masham zob. np.: H.R. Fox Bourne, The Life of John Locke. In Two Volumes, Harper \& Brothers Publishers, New York 1876, t. 2, ss. 210-215; The Correspondence of John Locke. In Eight Volumes, ed. E.S. de Beer, At the Clarendon Press, Oxford 1976, t. 2, ss. 470-472; A History of Women Philosophers. Volume III: Modern Women Philosophers, 1600-1900, ed. M.E. Waithe, Kluwer Academic Publishers, Dordrecht - Boston London 1991, ss. 73-85; J. Broad, Women Philosophers of the Seventeenth Century, Cambridge University Press, Cambridge 2004, ss. 114-140; J. Usakiewicz, Damaris Masham, jej zwiqzzi z Johnem Lockiem i dyskusja z Gottfriedem Wilhelmem Leibnizem, „Studia z Historii Filozofii” 3(9)/2018, ss. 103-116.

7 „[...] a book of Lady Masham's writing”; The Works of Mrs. Catharine Cockburn, Theological, Moral, Dramatic, and Poetical..., t. 2, ed. by Th. Birch, printed for J. and P. Knapton, London 1751, s. 190. Choć nie pada w tekście tytuł, to ze względu na datowanie listu bardziej prawdopodobne jest, że chodzi o Occasional Thoughts, niż o wydany w 1696 roku (również anonimowo) traktat Masham A Discourse Concerning the Love of God. 
for Their Writings Or Skill in the Learned Languages Arts and Sciences ${ }^{8}$. Dodajmy, że współcześnie nie kwestionuje się autorstwa Damaris Masham.

Te początkowe rozbieżności co do autorstwa Occasional Thoughts bez wątpienia wskazują na ogromną bliskość poglądów Masham i Locke’a, dotyczących choćby relacji religii naturalnej i religii objawionej, ścisłego związku religii z moralnością, poznania opierającego się na doświadczeniu zmysłowym, refleksji i rozumie, konieczności odpowiedniego wychowania dzieci od najmłodszych lat, jednak w kwestii najbardziej nas tu interesującej - edukacji kobiet, nie jest to już takie oczywiste ${ }^{9}$.

Pracą Locke’a, w której należałoby szukać zdania filozofa na temat edukacji kobiet, są z pewnością Myśli o wychowaniu (Some Thoughts Concerning Education). Locke choć zauważa na początku tego tekstu, że to właśnie wychowanie jest przyczyną wielkich różnic między ludźmi ${ }^{10}$, nie zamierzał bynajmniej zniwelować tych różnic między kobietami a mężczyznami poprzez odpowiednią edukację. Co prawda w tekście używa terminu „dziecko”, to jednak zwykle precyzuje, że chodzi o chłopców. Swoje rozważania zaś określa jako „ogólną metodę wychowania młodego szlachcica”"11. Już na pierwszych stronach przeczytamy też: „głównym celem tej rozprawy jest przedstawienie, jak winien być w dzieciństwie wychowywany młodzieniec, bowiem nie wszystkie moje wskazówki przydatne będą do wychowania córek; gdzie jednakże różnica płci wymaga odmiennego postępowania, nie trudno będzie dostrzec”"12. Czytając traktat dalej, zobaczymy, że owe przydatne wskazówki bezpośrednio odnoszące się do wychowania dziewcząt sprowadzają się

${ }^{8}$ Zob. G. Ballard, Memoirs of Several Ladies of Great Britain, Who Have Been Celebrated for Their Writings Or Skill in the Learned Languages Arts and Sciences, printed by W. Jackson, Oxford 1752, ss. 379-388.

${ }^{9}$ O możliwych wzajemnych wpływach w poglądach filozoficznych Masham i Locke zob. J. Broad, A Woman's Influence? John Locke and Damaris Masham on Moral Accountability, „Journal of the History of Ideas” Vol. 67, No. 3 (Jul. 2006), ss. 489-510.

10 Zob. J. Locke, Myśli o wychowaniu (Some Thoughts Concerning Education), §1 (wykorzystano wydanie w oryginale: The Works of John Locke, in Nine Volumes, The Twelfth Edition, t. 8, printed for C. and J. Rivington, T. Egerton, J. Cuthell, J. and A. Arch, Longman and Co., T. Cadell, J. Richardson, J. and W.T. Clarke, J. Mawman, Baynes and Son, Harding and Co., Baldwin and Co., Harvey and Darton, R. Scholey, J. Bohn, J. Collingwood, T. Tegg, G. and W.B. Whittaker, G. Mackie, W. Mason, Hurst, Robinson and Co., J. Hearne, J. Brumby, Simpkin and Marshall, S. Prowett, W. Pickering, R. Saunders, J. Parker, Oxford, and Stirling and Slade, Edinburgh, London 1824, oraz przekład na język polski: J. Locke, Myśli o wychowaniu, tłum. F. Wnorowski, Zakład Narodowy Imienia Ossolińskich Wydawnictwo Polskiej Akademii Nauk, Wrocław - Kraków 1959).

${ }^{11}$, „...] the general method of educating a young gentleman”; J. Locke, Myśli o wychowaпіи, §133.

12, „[... the principal aim of my discourse is, how a young gentleman should be brought up from infancy, which, in all things, will not so perfectly suit the education of daughters; though, where the difference of sex requires different treatment, it will be no hard matter to distinguish". Ibidem, §6. 
właściwie do rad, aby dziewczęta nie nosiły strojów: zbyt ciasnych - ze względu na zmiany zachodzące w ciele w okresie dorastania, zbyt strojnych - by nie wzbudzać w nich próżności ${ }^{13}$. Locke popiera wychowanie dziewcząt w odosobnieniu i skromności ${ }^{14}$. Zauważa również, że dobrą metodą nauki języka francuskiego jest uczenie się w praktyce poprzez obcowanie z francuską służącą lub guwernantką, i ten sposób należałoby według niego stosować również w nauczaniu języków chłopców ${ }^{15}$. Choć dostrzega rolę matki w wychowaniu dzieci w pierwszych latach ich życia, to nie wyciąga z tego wniosku, że konieczne jest zadbanie o edukację samych kobiet jako przyszłych matek. Wystarczy, jak można wnioskować ze słów Locke’a, aby kobieta bardzo dobrze umiała czytać i pisać w języku ojczystym ${ }^{16}$. Uważa, że matka może pomagać w nauce jakiejś dyscypliny czy też umiejętności, znając ją tylko powierzchownie. Czytamy:

I istotnie, nie zważając na hałas, jaki ludzie podnoszą w sprawie opanowania łaciny, jako ważnego i trudnego zadania, matka może dziecko sama tego nauczyć, jeśli zechce spędzić z nim tylko dwie lub trzy godziny dziennie i jeśli każe mu sobie czytać ewangelistów po łacinie. Wystarczy bowiem tylko, aby kupiła Nowy Testament po łacinie i aby dostawszy kogoś, kto by zaznaczył przedostatnią zgłoskę tam, gdzie ona jest długa, w wyrazach więcej niż dwuzgłoskowych (co wystarczy dla uporządkowania jej wymowy i akcentowania słów), czytała codziennie Ewangelię po angielsku, po czym nawet gdyby nie chciała, musi zrozumieć ją po łacinie. Kiedy zaś będzie rozumiała ewangelistów po łacinie, każ jej w ten sposób czytać bajki Ezopa i tak przejść dalej do Eutropiusa, Justyna i innych takich książek ${ }^{17}$.

${ }_{13}$ Zob. J. Locke, Myśli o wychowaniu, §11-12 oraz §37.

${ }_{14}$ Zob. ibidem, §70.

15 Zob. ibidem, §165.

16 Zob. np. ibidem, §163.

17 „And indeed, whatever stir there is made about getting of Latin, as the great and difficult business: his mother may teach it him herself, if she will but spend two or three hours in a day with him, and make him read the evangelists in Latin to her: for she need but buy a Latin testament, and having got somebody to mark the last syllable but one, where it is long, in words above two syllables (which is enough to regulate her pronunciation, and accenting the words), read daily in the gospels, and then let her avoid understanding them in Latin, if she can. And when she understands the evangelists in Latin, let her, in the same manner, read Aesop's fables, and so proceed on to Eutropius, Justin, and other books”. J. Locke, Myśli o wychowaniu, §177. Masham odwołując się do tego fragmentu, wskazuje, że można taki sposób nauczania rozszerzyć na podstawy innych nauk. Czytamy: „Pan L... na podstawie doświadczenia tegoż stwierdził, że matka, która nie rozumiała wcześniej łaciny, może uczyć jej swoje dziecko; co do tego, jeśli może, nie należy wątpić, ale może zrobić to samo z całą resztą; dla takiej powierzchownej wiedzy, jaka posłuży jako wstęp do każdej z wymienionych nauk [tj. arytmetyki, geografii, chronologii i historii - J.U.], jest to znacznie łatwiejsze do osiągnięcia niż co do języka łacińskiego; a jeżeli matka ma nawet tak niewiele więcej zdolności niż jej dziecko, może łatwo pozostawać przed nim w uczeniu razem obojga - jego i siebie samej, dzięki czemu najlepiej wynagrodzi sobie, jak może, swoje lub swoich rodziców przeszłe w tym zaniedbanie [...]”. („Mr. L... on the Experience thereof, has asserted, That a Mother who understands not Latin before hand, may yet teach it to her Child; which, if she can, it is not to be doubted but that she may do the same 
Możemy tu tylko oddać sprawiedliwość Locke’owi, że widzi w kobietach zdolnych samouków. Dodajmy, że w swoich rozważaniach Locke dużo uwagi poświęca rozwojowi fizycznemu dziecka oraz wykształceniu w nim pozytywnych cech charakteru - cnoty. Na drugi plan odsunął zaś kształcenie w ramach konkretnych dyscyplin nauki ${ }^{18}$.

Powróćmy jednak do Masham. Przyjrzymy się więc, jakie elementy rozumnego namysłu nad światem i człowiekiem, choć zbieżne z poglądami Locke’a, doprowadziły ją do bardziej postępowej i radykalnej na owe czasy konkluzji, że konieczną rzeczą jest odpowiednie wychowywanie i kształcenie kobiet. Przez cały tekst Occasional Thoughts przeplatają się trzy główne wątki: pesymistyczna ocena postępowania współczesnych Masham, koncepcja teoretyczna człowieka jako istoty racjonalnej oraz edukacja, w szczególności kobiet, jako remedium na złą kondycję współczesności. Mówiąc inaczej, Masham przedstawia to, co jest; to, co być powinno oraz co należy zrobić, żeby to, co jest, stało się tym, co być powinno.

W swojej krytyce Masham skupia się na: ukazaniu błędnego postępowania ludzi, a więc działania wbrew nakazom rozumu, wypaczeniu starożytnej cnoty oraz sprowadzeniu religii do nauki katechizmu jako zbioru niezrozumiałych nakazów i zakazów, spekulacji teologicznych oraz skupieniu się na zewnętrznych oznakach kultu. Krytyka jest jednocześnie punktem wyjścia rozważań teoretycznych nad światem oraz dla poszukiwania środka zaradczego na złą kondycję ludzi. Czytamy:

[Przemyślenia - J.U.] biorą swój początek z konkretnego badania, a następnie przechodzą do ogólnego rozważania głupoty i szaleństwa działania rozumnego stworzenia, tak jakby [rozumne stworzenia - J.U.] nie miały żadnej innej zasady nimi kierującej lub je determinującej niż podburzanie przez ich namiętności i skłonności, obejmując zarazem nieszczęścia rodzaju ludzkiego zarówno tu, jak i w przyszłym życiu. Ponieważ te naruszenia wiecznego prawa rozumu, które wprowadzają nieporządek we wspólnotach i królestwach, zakłócają spokój rodzin i powodują największą część prywatnych nieszczęść poszczególnych osób na tym świecie, są tym, co Władca rozporządzający wszystkimi rzeczami ustanowił jako to, co uczyni ludzi nieszczęśliwymi także w przyszłym życiu19 ${ }^{19}$.

of all the rest; for such a Superficial Knowledge as will serve to enter any one in every of the above-named Sciences, is much easier attain'd than the Latin Tongue; and if a Mother have ever so little more Capacity than her Child, she may easily keep before him, in teaching both him and her self together; whereby she will make herself the best Reparation that she can for her past neglect, or that of her Parents herein”. OT, s. 196; przekład wszystkich cytatów z tego dzieła Joanna Usakiewicz.

${ }^{18}$ Zob. J. Locke, Myśli o wychowaniu, §147.

19 „The which taking their rise from a particular Enquiry, and thence proceeding to a general Consideration of the Folly and Madness of Rational Creature's acting, as if they had no other Principle to direct or determin them, than the Incitements of their Passions and Appetites, comprehended at once the unhappiness of Mankind, both Here and Hereafter. Since those Breaches of the Eternal Law of Reason, which disorder Common-wealths and Kingdoms; disturb the Peace of Families; and make by far the greatest part of the Private Infelicities of Particular Persons in this World, are what the Sovereign Disposer of all things has ordain'd, shall render Men miserable in a future Life also". OT, s. 2. 
Ludzie działają pobudzani swoimi namiętnościami i skłonnościami, a nie rozumem, zapominając o perspektywie życia po śmierci. Skłonności i namiętności, według Masham, wpisane są jednak w ludzkie dążenie do szczęścia: „miłość do szczęścia (które polega na przyjemności) jest najwcześniejszą i najsilniejszą zasadą ludzkiej natury”20. Pragnienia (desires) i skłonności (appetites) wskazują człowiekowi owe przyjemności, każdy zmysł dostarcza czegoś, co prowadzi do zadowolenia, także same operacje umysłu na ideach mogą dawać przyjemność. Jako stworzenia rozumne powinniśmy jednak dążyć do największego szczęścia, do którego jesteśmy zdolni, a ono będzie następstwem przyjemności największej, czyli tej, która musi być związana z nakazami rozumu jako właściwego, przynależnego tylko jednemu stworzeniu - człowiekowi.

Przytoczony początkowy krytyczny fragment zawiera bardzo istotne elementy Masham koncepcji świata, która zostaje w dalszym ciągu wywodu przez nią rozwinięta, stanowiąc punkt odniesienia dla wniosków na temat edukacji. Człowiek jest stworzeniem, a więc został powołany do istnienia przez Tego, który tu nazywany jest Władcą, przez Boga. Bóg jest „niewidzialny, wszechwiedzący, wszechmocny, jest pierwszą przyczyną wszystkich rzeczy”21. O istnieniu Boga poucza człowieka rozum naturalny dzięki wiedzy o istnieniu samego siebie i doświadczeniu świata zewnętrznego:

Jeśli chcemy zobaczyć, jakie światło otrzymujemy od Natury, aby kierować naszymi działaniami, i jak dalece jesteśmy w stanie być posłuszni temu światłu, powinniśmy ludzi rozważać tak, jakby znajdowali się w stanie natury, to znaczy jako nie poddanych żadnemu zewnętrznemu prawu do kierowania sobą, lecz obdarzonych jedynie zdolnością porównywania swoich odległych idei za pośrednictwem idei pośrednich, i na tej podstawie dedukujących lub wnioskujących o jednej rzeczy z drugiej, dzięki czemu nasza wiedza bezpośrednio otrzymana od zmysłu lub przez refleksję zostaje rozszerzona do zobaczenia prawd odległych lub przyszłych, a przez zastosowanie tej zdolności umysłu do rozważenia naszego własnego istnienia i natury razem z pięknem i porządkiem Wszechświata, tak daleko jak podpada to pod nasz ogląd, możemy dojść do wiedzy o Pierwszej Przyczynie, oraz do tego, że musi nią być Byt Rozumny, Mądry i Potężny, przewyższający wszystko, co jesteśmy w stanie pomyśleć ${ }^{22}$.

${ }^{20}$, „[...] the love of happiness (which consists in pleasure) is the earliest, and strongest principle of Humane Nature”. OT, s. 71.

${ }^{21}$ „Invisible, Omniscient, Omnipotent, first Cause of all things”. OT, s. 31.

22 „To see what light we receive from Nature to direct our Actions, and how far we are Naturally able to obey that Light; Men must be consider'd purely as in the state of Nature, viz. as having no extrinsick Law to direct them, but indu'd only with a faculty of comparing their distant Ideas by intermediate Ones, and Thence of deducing, or infering one thing from another; whereby our Knowledge immediately received from Sense, or Reflection, is inlarg'd to a view of Truths remote, or future, in an Application of which Faculty of the mind to a consideration of our own Existence and Nature, together with the beauty and order of the Universe, so far as it falls under our view, we may come to the knowledge of a First Cause; and that this must be an Intelligent Being, Wise and Powerful, beyond what we are able to conceive”; OT, ss. 60-61. 
Masham precyzuje myśl o poznaniu Boga przez doświadczenie świata zewnętrznego:

I tak przez rozważenie atrybutów Boga widocznych w dziełach stworzenia dochodzimy do wiedzy o Jego istnieniu [o istnieniu Tego - J.U.], który jest Bytem Niewidzialnym. A ponieważ Moc, Mądrość i Dobroć, które w sposób oczywisty dostrzegamy w tworzeniu i zachowywaniu nas samych i Wszechświata, nie mogłyby istnieć niezależnie od jakiejś substancji, do której by przynależały, zostaliśmy upewnieni, że istnieje substancja, do której one należą lub której są atrybutami ${ }^{23}$.

Celem człowieka jako stworzenia Boga jest osiągnięcie zbawienia, zasłużenie na nagrodę po śmierci:

[...] jest pewne, że tym, co przede wszystkim powinniśmy wiedzieć, jest to, co jest konieczne do naszego zbawienia, jak też jest równie pewne, że cokolwiek Bóg uczynił koniecznym dla naszego zbawienia, w tym samym czasie jesteśmy zdolni poznać ${ }^{4}$.

Człowiek został jednak obdarzony przez Boga wolnością - ma swobodę działania zgodnie z własnymi preferencjami:

Zostaliśmy następnie obdarzeni [...] wolnością działania lub nie, odpowiednio i zgodnie do tego [tj. rozróżniania różnic rzeczy], zatem możemy w zgodzie z preferencją naszych własnych umysłów działać albo w zgodzie, albo w niezgodzie z wolą Stwórcy [... $]^{25}$.

Człowiek jest wolny do tego stopnia, że ma możliwość przeciwstawienia się Bogu. Wolność jest związana bezpośrednio z niedoskonałością stworzenia - istnieniem w świecie wad i cnót. Masham pisze:

Lecz bez zdolności stworzenia do działania wbrew woli Stwórcy nie może być w żadnej stworzonej istocie jakiejkolwiek wady lub właściwej jej doskonałości; przeciwstawienie się woli Boga jest zatem dozwolone we Wszechświecie jako konieczne następstwo niedoskonałości stworzenia zgodnie z największym darem, jaki stworzona istota ma zdolność posiadać, to jest z tq wolnościq̨ lub swobodq działania. A taka właśnie konstytucja stworzenia implikuje, że to, co jest najlepsze w odniesieniu do projektu Stwórcy i jego własnego szczęścia, nie zawsze powinno z konieczności przedstawiać się umysłowi

Por. J. Locke, Rozważania dotyczq̨ce rozumu ludzkiego (An Essay Concerning Human Understanding), księga IV, rozdz. 10.

${ }^{23}$ „And thus, by a consideration of the Attributes of God, visible in the Works of the Creation, we come to a knowledge of his Existence, who is an Invisible Being: For since Power, Wisdom and Goodness, which we manifestly discern in the production and conservation of our selves, and the Universe, could not subsist independently on some substance for them to inhere in, we are assur'd that there is a substance where unto they do belong, or of which they are the Attributes”. OT, s. 62.

${ }^{24}$, „[...] it is certain that what we are in the first place concern'd to know, is that which is necessary to our Salvation; and it is as certain that whatever God has made necessary to our Salvation, we are at the same time capable of knowing”. OT, s. 42.

${ }^{25}$ „We being then indu'd [...] with a liberty of acting, or not, suitably and agreeably hereunto; whence we can according to the preference of our own minds, act either in conformity to, or disconformity with, the Will of the Creator”. OT, s. 64. 
jako najlepsze. Takie stworzenie może przeciwstawić się woli swojego Stworzyciela z różnymi stopniami winy w tym, co robi, lub (co możliwe) bez żadnej, ponieważ żaden podmiot działający nie może popełniać wykroczeń ponad to, że świadomie nadużywa wolności, z którą musi działać ${ }^{26}$.

Człowiek jest wszak rozumny: działaniem dla niego specyficznym jest więc działanie rozumne - to jest jego cnota. Ludzie współcześni Masham wypaczyli jednak według niej pojmowanie cnoty. Cnotę w stosunku do mężczyzn sprowadzili do zachowania i dbania o reputację (reputation) czy też dobre imię (good name), a w stosunku do kobiet do czystości cielesnej (chastity): „Termin [cnota - J.U.], kiedy stosowany jest wobec kobiet, rzadko wybierany jest przez niektórych ludzi na oznaczenie jakiejkolwiek rzeczy oprócz pojedynczej cnoty czystości”27. Tak rzadko kojarzy się cnotę w odniesieniu do płci żeńskiej z zaletami umysłu, że właściwie można ją przyrównać do zdrowia, urody czy młodości - sprowadzona została do cielesności. A przecież, jak pisze Masham:

[...] cnota nie sprowadza się (chociaż często tak jest błędnie przedstawiana) do niewinności, ani nie polega na upodobaniu do praktykowania działań godnych pochwały; jej zasięg jest równy naszej wolności działania, a jej zasada jest tą najbardziej aktywną [zasadą - J.U.] umysłu; cnota jest naturalnym wynikiem szczerego pragnienia podporządkowania się we wszystkich rzeczach prawu nadanemu nam przez naszego Stwórcę $[\ldots]^{28}$.

Odnosząc cnotę w szczególności do kobiet, Masahm również bardzo wyraźnie łączy ją z posłuszeństwem Bogu:

[...] prawdziwa cnota jest najlepszą obroną przeciwko wszystkim nieszczęściom, których można się obawiać, i najpewniejszą rękojmią wszystkich pociech, które mogą być nadzieją dla żony; to jest taka cnota, której podstawą jest pragnienie ponad wszystko aprobaty Boga; najbardziej przeciwna zasadzie, która polega na uczynieniu szacunku u ludzi najwyższym celem i zamiarem naszych działań $[\ldots]^{29}$.

26 „But as without a capacity in The Creature to act contrary to the will of the Creator there could be no defect, or self-excellency in any Created Being; contrariety to the Will of God is therefore permitted in the Universe as a necessary result of Creaturely imperfection, under the greatest endowment that a Created Being is capable of having, viz. That of Freedom or Liberty of Action: And as the constitution of such Creature, as this, implies that what is best in reference to the design of the Creator, and of its own Happiness, should not be always necessarily present to the Mind as Best; such a Creature may oppose the Will of his Maker with various degrees of Guilt in so doing; or (possibly) with none at all; for no Agent can offend farther than he wilfully abuses the Freedom he has to act”. OT, ss. 69-70.

${ }^{27}$ „A Term [Vertue] which when apply'd to Women, is rarely design'd, by some People, to signifie any thing but the single Vertue of Chastity”. OT, s. 21.

28 „But Vertue is not (tho often so misrepresented) included in Innocency; or does consist in a partial Practice of Actions praiseworthy; for its extent is equal to our liberty of Action; and its Principle the most Active one of the Mind; Vertue being the natural result of a sincere desire to conform in all things to the Law set us by our Maker”. OT, s. 11.

29, „[...] a true Vertue is the best Security against all the Misfortunes that can be fear'd, and the surest Pledge of all the Comforts that can be hop'd for in a Wife, viz. such a Vertue whose 
W osiągnięciu cnoty pomaga człowiekowi religia. Mowa tu religii naturalnej, którą wspomaga religia objawiona ${ }^{30}$. Czytamy:

Istnienie Boga jest uznane za prawdę tak wcześnie przez nas odebraną i tak oczywistą dla naszego rozumu, że wygląda jak naturalna inskrypcja; autorytet tego Objawienia, dzięki któremu Bóg oznajmił swoją wolę ludziom, jest tak mocno utrwalony w umysłach ludzi na podstawie jego najczystszej i najbardziej racjonalnej oczywistości. W konsekwencji tego ludzie później są kierowani do samych Pism, aby zobaczyć w nich to, czego Bóg od nich wymaga do wierzenia i do czynienia; wielkim ich obowiązkiem jest pilnie studiować te Boskie Wyrocznie należycie im przedstawione ${ }^{31}$.

\section{Lub w innym miejscu:}

Religia jest (jak to teraz przyjmuję za pewnik) jedyną wystarczającą podstawą lub solidną podporą cnoty, gdyż wiara w Wyższy, Wszechmocny Byt kontrolujący nasze działania, który będzie odpowiednio nagradzał i karał, jest we wszystkich ludzkich rozumowaniach najmocniejszym i po prawdzie jedynym trwałym i nieodpartym argumentem dla podporządkowania naszych pragnień stałym nakazom $[\ldots]^{32}$.

W tej perspektywie religia zostaje ściśle powiązana z moralnością: „Religia, jak sądzę, słusznie została zdefiniowana jako wiedza o tym, jak podobać się Bogu, i tak rozumiana koniecznie zawiera cnotę, to znaczy moralną prawość [...]”33.

Bardzo istotną rolę odgrywa rozum w kwestiach Objawienia. Każdy autorytet, każde twierdzenie powinno podlegać jego osądowi: „zgoda na jakąkolwiek rzecz powinna być regulowana przez taki dowód jej prawdy, w którym rozum jest sędzią [...]”34. Rozum Masham definiuje zaś następująco: „Przez rozum pojmowana

Foundation is a desire above all things, of approving our selves to God; the most opposite Principle whereunto is the making the Esteem of Men the chief End, and Aim of our Actions”. OT, s. 23.

${ }^{30}$ Masham odsyła w tej kwestii do traktatu Locke’a The Reasonableness of Christianity as Delivered in the Scriptura. Por. też J. Locke, Rozważania dotyczq̨ce rozumu ludzkiego, księga IV, rozdz. 18-19.

31 „The existence of God being acknowledg'd a Truth so early receiv'd by us, and so evident to our Reason, that it looks like Natural Inscription; the Authority of that Revelation by which God has made known his Will to Men, is to be firmly establish'd in People's Minds upon its clearest, and most rational evidence; and consequentially They are then to be refer'd to the Scriptures themselves, to see therein what it is that God requires of them to believe and to do; the great Obligation they are under diligently to study these Divine Oracles being duly represented to them". OT, s. 43.

32 „Religion being (as I shall take it at present for granted) the only sufficient ground or solid support of Vertue; For the belief of a Superior, Omnipotent Being, inspecting our Actions, and who will Reward or Punish us accordingly, is in all Men's Apprehensions the strangest, and in truth the only stable and irresistible Argument for submitting our Desires to a constant Regulation”. OT, 14. Por. J. Locke, Rozważania dotyczqce rozumu ludzkiego, ksiega IV, rozdz. 10, 7.

${ }^{33}$ „Religion has, I think, been rightly defin'd to be the knowledge how to please God, and thus taken, does necessarily include vertue, that is to say, Moral Rectitude”. OT, s. 84.

34, „[...] assent to anything, ought to be govern'd by that proof of its Truth, whereof Reason is the Judge [...]”. OT, 33. Na temat kwestii rozumu w pismach Masham zob. M.P. Lascano, 
jest tutaj zdolność w nas, która odkrywa za pośrednictwem idei, jakie połączenie w twierdzeniu ma jedno z drugim: czy pewne, prawdopodobne czy żadne; zgodnie z czym powinniśmy regulować naszą zgodę. Jeśli tego nie robimy, degradujemy się co do bycia stworzeniami racjonalnymi i pozbawiamy samych siebie jedynego przewodnika, którego Bóg dał nam dla naszego postępowania w naszych działaniach i poglądach”35. Objawienie także należy osądzić rozumem:

Wprawdzie rozum nie może z oczywistości rzeczy sam wywołać naszej zgody na jakieś twierdzenie, gdy nie możemy dostrzec związku idei w nim zawartych, jeśli jednak jawi się, że takie twierdzenie zostało prawdziwie objawione przez Boga, nic nie może być bardziej rozumne, niż wierzyć w nie, ponieważ wiemy, że Bóg nie może ani zwodzić, ani być zwodzony; że są prawdy wykraczające poza nasze pojmowanie; i że Bóg może (jeśli tak sobie życzy) przekazać je nam przez nadprzyrodzone Objawienie ${ }^{36}$.

Dla Masham oczywiste jest bowiem, że „irracjonalna religia nigdy nie może być rozumnie uznana za pochodzącą od Boga" ${ }^{37}$.

Splot rozumności człowieka, religii i moralności powoduje, iż konieczna staje się edukacja: „Właściwe i zdecydowane egzekwowanie odpowiednich praw przeciw niemoralności i bluźnierczości jest jedynym, co skutecznie je powstrzyma, a prawdziwa troska o edukację jest jedynym ludzkim środkiem, aby uczynić ludzi prawdziwie cnotliwymi”38. Swoistą pochwałę edukacji zawarła Masham w słowach:

Aby pokazać nam, jaką moc ma nad naszymi umysłami edukacja i jak dzięki należytemu poszanowaniu przyczyniła się do tego, że wspólnoty i królestwa kwitły i stawały się sławne, i jak bardzo było to polecane przez mędrców we wszystkich czasach, potrzeba jedynie dobrego rozważenia natury ludzkiej i znajomości historii; nie ma też niczego bardziej oczywistego niż moc edukacji ${ }^{39}$.

Damaris Masham and „the Law of Reason or Nature”, „,The Modern Schoolman” 88(3/40)/2011, ss. 245-265.

35 „By Reason being here understood that Faculty in us which discovers, by the intervention of intermediate Ideas, what Connection Those in the Proposition have one with another: Whether certain; probable; or none at all; according whereunto, we ought to regulate our Assent. If we do not so, we degrade our selves from being Rational Creatures; and deprive our selves of the only Guide God has given us for our Conduct in our Actions and Opinions”. OT, s. 33.

${ }^{36}$ „For tho' Reason cannot from the Evidence of the thing it self induce our assent to any Proposition, where we cannot perceive the Connexion of the Ideas therein contain'd; yet if it appears that such a Proposition was truly reveal'd by God, nothing can be more Rational than to believe it: since we know that God can neither Deceive, nor be Deceived: That there are Truths above our Conception, and that God may (if he so pleases) communicate these to us by Supernatural Revelation”. OT, s. 34.

37, „...] an Irrational Religion can never Rationally be conceived to come from God”. OT, s. 36.

38 „A due and vigorous Execution of proper Laws against Immorality and Prophaneness, is that alone which will effectually restrain them: And a right care had of Education, is the only humane means of making People truly Vertuous”. OT, s. 5-6.

39 „What the force of Education is upon our Minds, and how by a due regard had to it, Common-wealths and Kingdoms have flourished, and become famous; and how much this has been 
Dotychczasowe doświadczenie pokazuje jednak, że edukacja była albo niedostępna, albo ograniczona ze względu na płeć. Czytamy:

Ale co do tego pominięcia w odniesieniu do jednej płci, wyraźnie należy przyznać, że ten trud, który często nakładany jest na drugą, tak często jak to ma miejsce, okazuje się nieskuteczny: stąd faktyczna pomoc matek (mówiąc ogólnie) będzie uznana za konieczną dla właściwego kształtowania umysłów ich dzieci obojga płci; a wrażenia odebrane w młodym wieku, którego większa część nieuchronnie upływa wśród kobiet, mają znaczące konsekwencje dla ludzi przez całą resztę ich życia jako posiadające silny i często ostateczny wpływ na ich przyszłe inklinacje i namiętności ${ }^{40}$.

Współczesne sobie wychowanie dziewcząt Masham opisuje dobitnie w następujących słowach: „dziewczęta między głupimi ojcami i nieuczonymi matkami są generalnie tak wychowywane, że tradycyjne mniemania przez całe życie zastępują im rozum”“11. Masham dostrzega konieczność zmiany tej sytuacji, upomina się więc o kształcenie kobiet. Opierając się na przedstawionej koncepcji świata, argumentuje na rzecz edukacji kobiet jako stworzeń rozumnych, dążących do zbawienia, mających do odegrania ważne role w społeczeństwie.

Bóg obdarzył kobietę rozumem, a więc nie chciałby, aby z niego nie korzystała i nie doskonaliła się poprzez uczenie. Przecież każdy zna ewangeliczne zalecenie dla ludzi, wzywające do: „,wykorzystania ich czasu i talentów jako rzeczy, z których pewnego dnia trzeba będzie zdać rachunek"42. Każdy człowiek bez względu na płeć ma swoje miejsce i zadanie w świecie, został przez Boga stworzony do działania:

[...] nikt nie narodził się na świecie, aby żyć bezczynnie, ciesząc się owocem i korzyścią innych pracujących ludzi bez wzajemnego wkładu w taki czy inny sposób w dobro wspólnoty odpowiednio do tego stanu, w którym go umieścił Bóg (wspólny Ojciec wszystkich), który w sposób oczywisty zamierzył rodzaj ludzki jako członki tego samego ciała, użyteczne każdy dla każdego w swoich odpowiednich miejscach ${ }^{43}$.

recommended by Wise Men in all Ages, requires but a small consideration of Humane Nature, and Acquaintance with History to inform us; nor is any thing more obvious to observe than the power of Education”. OT, ss. 6-7.

40 „But to this omission in respect of one Sex, it is manifestly very much to be attributed, that that pains which is often bestow'd upon the other, does so frequently, as it does, prove ineffectual: Since the actual assistance of Mothers, will (generally speaking) be found necessary to the right forming of the Minds of their Children of both Sexes; and the Impressions receiv'd in that tender Age, which is unavoidably much of it passed among Women, are of exceeding consequence to Men throughout the whole remainder of their Lives, as having a strong and oftentimes unalterable influence upon their future Inclinations and Passions”. OT, s. 7.

41 „[...] Girls, betwixt silly Fathers and ignorant Mothers, are generally so brought up, that traditionary Opinions are to them, all their lives long, instead of Reason”. OT, s. 162.

42, „[...] the improvement of their Time, and Talents, as things whereof they must one Day be accountable”. OT, s. 152.

${ }^{43}$, „[...] no one is Born into the World to live idly; enjoying the Fruit and Benefit of other Peoples Labours, without contributing reciprocally some way or other, to the good of the Community answerably to that Station wherein God (the common Father of all) has plac'd them; 
Edukacja ważna jest również przez wzgląd na indywidualne zbawienie:

Jeśli chrześcijaństwo jest religią od Boga, a kobiety mają dusze przeznaczone do zbawienia tak samo jak mężczyźni, to wiedzieć, z czego ta religia się składa, i rozumieć podstawy, na jakich jest przyjmowana, jest bardziej niż konieczną wiedzą tak dla kobiety, jak i dla mężczyzny ${ }^{44}$.

Kształcenie kobiet jest konieczne również, jeśli weźmiemy pod uwagę ich role społeczne. Masham szczególnie podkreśla rolę matki: „Doskonalenie rozumu wszelako konieczne jest dla ogłady dam jako racjonalnych stworzeń; i jako potrzebne dla dobrej edukacji ich dzieci oraz, aby były użyteczne dla swoich rodzin [...]”45. Bardzo istotne jest, aby kobieta jako pierwsza przekazicielka wiary rozumiała podstawy wyznawanej religii:

Jest bowiem niezaprzeczalną prawdą, że pani, która jest w stanie wyjaśnić swoją wiarę i bronić swojej religii przed atakami krytykujących kpiarzy swego wieku lub obelgami narzucających próżne mniemania, jest w stanie pouczyć swoje dzieci co do racjonalności religii chrześcijańskiej i dać im podstawy mocnej cnoty $[\ldots]^{46}$.

Nie pomija także roli żony. Choć uważa, że nie możemy sformułować idei tak wielkiego szczęścia, jakie można znaleźć w jakiejś rzeczy w tym życiu, jak w stanie małżeńskim" ${ }^{47}$, to zastrzeżone jest ono dla dwojga ludzi rozumnych i cnotliwych, którzy wzajemne uszczęśliwianie się mają za „obowiązek i przedmiot zainteresowania” (duty and interest) ${ }^{48}$. Masham zdaje sobie sprawę, że wiele kobiet jest nieszczęśliwych w małżeństwie. Zauważa więc, iż edukacja kobiet może być dla nich najlepszym lekarstwem na nieudany związek - wykształcona kobieta umie znaleźć sobie odpowiednie zajęcie i nie będzie pogrążać się we frustracji i żalu:

Mam na myśli wszystkie tak nieszczęśliwie zamężne, w czym tak dobre wynagrodzenie mogą one znaleźć za nieszczęście posiadania głupich i złośliwych mężów, którzy je

who has evidently intended Humane kind for Society and mutual Communion, as Members of the same Body, useful every one each to other in their respective places”. OT, s. 179.

${ }^{44}$ „For if Christianity be a religion from God, and women have souls to be saved as well as men; to know what this religion consists in, and to understand the grounds on which it is to be received, can be no more than necessary knowledge to a woman, as well as to a man [...]". OT, ss. 165-166.

45 „The improvements of reason, however requisite to ladies for their accomplishment, as rational creatures; and however needful to them for the well educating of their children, and to their being useful in their Families [...]”. OT, ss. 161-162.

46 „For it is an undeniable Truth that a Lady who is able but to give an account of her Faith, and to defend her Religion against the attaques of the Cavilling Wits of the Age; or the Abuses of the Obtruders of vain Opinions: That is capable of instructing her Children in the reasonableness of the Christian Religion; and of laying in them the Foundations of a solid Vertue”. OT, ss. $174-175$.

47 „[...] we cannot frame an Idea of so great Happiness to be found in any thing in this Life, as in a Marry'd State”. OT, s. 217.

${ }^{48}$ OT, s. 216. 
lekceważą lub źle traktują, jak mając dzieci poważane za ich cnoty i takie, które będą je poważać i kochać nie tylko jako swoich rodziców, lecz jako te, którym zawdzięczają więcej niż swoje istnienie? ${ }^{49}$

Według Masham mężczyźni powinni także pragnąć rozumnych żon: rozumność wykształconej żony to najlepsze zabezpieczenie wierności małżeńskiej. Nieco sentencjonalnie podsumowuje rozważania na ten temat: „podczas gdy łatwa ignorancja jest postrzegana jako ofiara wystawiona na łup każdego śmiałego najeźdźcy, i w jakikolwiek strój powagi lub skromności przy tym jest ubrana, zaprasza tak bardzo często, nawet kiedy uroki osoby skądinąd nie przyciągałyby go"50.

Masham wspomina także o kształceniu kobiet w różnych dyscyplinach nauki: „Teraz w pogoni za przyjemnością, która daje ćwiczenie i doskonalenie zdolności intelektualnych, nie widzę powodu, dla którego nie powinno się uważać, że

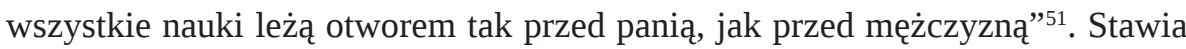
jednak warunek, aby wiedza wiązała się z obowiązkami kobiety i była właściwa jej płci i stanowi.

Warto w tym miejscu zauważyć, że argumenty Masham, w których odwołuje się do rozumności kobiet, ich zbawienia, obrony religii oraz to, że uznaje, iż kobiety mogą zgłębiać różne dyscypliny nauki, zbieżne jest z tym, co przedstawiła Anna Maria van Schurman (1607-1678) w Dissertatio de ingenii muliebris ad doctrinam et meliores litteras aptitudine. Accedunt quaedam epistolae, eiusdem argumenti. Główna część tej książki została przełożona na język angielski i wydana w roku 1659, czyli w roku urodzenia Damaris Masham, jako The Learned Maid or Whether a Maid May Be a Scholar? A Logick Exercise; Written in Latine by That Incomparable Virgin Anna Maria à Schurman of Utrecht, With Some Epistles to the Famous Gassendus and Others ${ }^{52}$. Nie ma jednak dowodu na to, że Masham książkę tę znała.

49 „I mean all such as are unhappily Marry'd; for what so good Reparation can they find for the misfortune of having foolish and vicious Husbands, who neglect or treat them ill, as the having Children honour'd for their Vertue, and who shall honour and love them, not only as their Parents, but as those to whom they owe much more than their Being?”. OT, ss. 220-221.

50, ,...] whilst easy ignorance is look'd upon as a Prey expos'd to every bold Invader: And whatever Garb of Gravity or Modesty it is cloath'd withal, invites such very often, even where the Charms of the Person would not otherwise attract them”. OT, s. 211.

51 „Now in the pursuit of that Pleasure which the exercise and improvement of the understanding gives, I see no Reason why it should not be thought that all Science lyes as open to a Lady as to a Man”. OT, s. 227.

${ }^{52}$ Anna Maria van Schurman, Dissertatio de ingenii muliebris ad doctrinam et meliores litteras aptitudine. Accedunt quaedam epistolae, eiusdem argumenti, Ex Officina Elseviriana, Lejda 1641. Przekład Dissertatio na język polski: A.M. van Schurman, Problem praktyczny: Czy chrześcijańskiej kobiecie przystoi zamiłowanie do studiowania nauk?, przekład i opracowanie J. Usakiewicz, „Studia z Historii Filozofii” 1(10)/2019, ss. 17-38. Zob. też J. Usakiewicz, Anna Maria van Schurman (1607-1678) - Ocellus Niderlandów, „Studia z Historii Filozofii” $1(10) / 2019$, ss. $171-192$. 
Damaris Masham, podzielając poglądy Locke’a, łącząc rozważania natury filozoficznej i teologicznej, przekroczyła w swoich rozmyślaniach ograniczenia porządku społeczno-kulturowego swojej epoki, upominając się o edukację kobiet. W jej argumentacji zwraca uwagę nie tylko odwołanie się do kwestii teologicznych i filozoficznych, ale także swoisty pragmatyzm. W patriarchalnym społeczeństwie należy przekonać mężczyzn - a więc skoro trudno im przyznać, że kobieta jest równa mężczyźnie jako rozumne stworzenie, to może przemówi do nich czysto praktyczna kwestia właściwego początkowego wychowywania dzieci, a chłopców w szczególności, przez matki, czy też wierności żony.

\section{Literatura}

A History of Women Philosophers. Volume III: Modern Women Philosophers, 1600-1900, Ed. Mary Ellen Waithe, Kluwer Academic Publishers, Dordrecht/Boston/London 1991. Ballard G., Memoirs of Several Ladies of Great Britain, Who Have Been Celebrated for Their Writings Or Skill in the Learned Languages Arts and Sciences, printed by W. Jackson, Oxford 1752.

Boyer A., The History of the Reign of Queen Anne. Digested into Annals. Year the Third, A. Roper, London 1705.

Broad J., A Woman's Influence? John Locke and Damaris Masham on Moral Accountability, „Journal of the History of Ideas” Vol. 67, No. 3 (Jul. 2006).

Broad J., Women Philosophers of the Seventeenth Century, Cambridge University Press, Cambridge 2004.

Fox Bourne H.R., The Life of John Locke. In Two Volumes, t. 2, Harper \& Brothers Publishers, New York 1876.

Lascano Marcy P., Damaris Masham and „the Law of Reason or Nature”, „The Modern Schoolman” 88(3/40)/2011.

Locke J., Myśli o wychowaniu, tłum. Feliks Wnorowski, Zakład Narodowy Imienia Ossolińskich Wydawnictwo Polskiej Akademii Nauk, Wrocław - Kraków 1959.

Locke J., Rozważania dotyczq̨ce rozumu ludzkiego, t. 2, tłum. B.J. Gawecki, PWN, Warszawa 1955.

Locke J., The Reasonableness of Christianity as Delivered in the Scriptura, Printed for Awnsham and John Churchil, at the Black Swan in Pater-noster-row, London 1695.

Locke J., Some Thoughts Concerning Education, Printed for A. and J. Churchill at the Black Swan in Pater-noster-row, London 1693.

[Masham D.], Occasional Thoughts in Reference to a Vertuous or Christian Life, printed for A. and J. Churchil at the Black Swan in Pater-noster Row, London 1705.

Pylades and Corinna: or; Memoirs of the Lives, Amours, and Writings of Richard Gwinnett and Mrs. Elizabeth Thomas, Edmund Curll, London 1731.

Schurman A.M. van, Dissertatio de ingenii muliebris ad doctrinam et meliores litteras aptitudine. Accedunt quaedam epistolae, eiusdem argumenti, Ex Officina Elseviriana, Lejda 1641. 
Schurman A.M. van, Problem praktyczny: Czy chrześcijańskiej kobiecie przystoi zamiłowanie do studiowania nauk?, przekład i opracowanie Joanna Usakiewicz, „Studia z Historii Filozofii” 1(10)/2019.

The Correspondence of John Locke. In Eight Volumes, t. 2, ed. Esmond Samuel de Beer, At the Clarendon Press, Oxford 1976.

The Works of John Locke, in Nine Volumes, The Twelfth Edition, t. 8, printed for C. and J. Rivington, T. Egerton, J. Cuthell, J. and A. Arch, Longman and Co., T. Cadell, J. Richardson, J. and W.T. Clarke, J. Mawman, Baynes and Son, Harding and Co., Baldwin and Co., Harvey and Darton, R. Scholey, J. Bohn, J. Collingwood, T. Tegg, G. and W.B. Whittaker, G. Mackie, W. Mason, Hurst, Robinson and Co., J. Hearne, J. Brumby, Simpkin and Marshall, S. Prowett, W. Pickering, R. Saunders, J. Parker, Oxford, and Stirling and Slade, Edinburgh, London 1824.

The Works of Mrs. Catharine Cockburn, Theological, Moral, Dramatic, and Poetical..., t. 2, ed. by Thomas Birch, printed for J. and P. Knapton, London 1751.

Thoughts on Christian Life by John Locke, T. Waller, London 1747.

Usakiewicz J., Anna Maria van Schurman (1607-1678) - Ocellus Niderlandów, „Studia z Historii Filozofii” 1(10)/2019.

Usakiewicz J., Damaris Masham, jej zwiqzzi z Johnem Lockiem i dyskusja z Gottfriedem Wilhelmem Leibnizem, “Studia z Historii Filozofii” 3(9)/2018. 
